\title{
Framework for Forward Planning
}

CANADIan science is now well on the way to being the best managed, or at least the most self-consciously managed, of any country in the West. In their latest, report, The Role of the Federal Government in Support of Research in Canadian Universities, the Science Council of Canada and the Canada Council put forward far-reaching suggestions for the reorganization of the policy-making bodies concerned with Canadian science. The report is the outcome of a study carricd out under the chairmanship of Dr J. B. Macdonald.

In several ways, Canadian science has been doing well in recent years. In 1963-64 the total expenditure on research and development in Canada amounted to $\$ 425$ million, about half what was then spent in France but only a fiftieth of the comparable expenditure in the United States. Since then, however, Canadian expenditure has grown rapidly and, in the National Research Council and the Medical Research Council, the sums of money allocated for university research increased by between 30 and 35 per cent a year in the past four years. The result is that the university budget of the two research councils has multiplied fifteen times in a decade to $\$ 88$ million. In the social sciences and the humanities, growth is even faster, the total expenditure doubling each year. Much of the argument in the report is based on an assessment of the problems of relating research and social goals, which entails meticulous examination of the part played by the universities. The Macdonald committee is happily sensitive to the need that governments should not regard universities as "a pool of talent automatically on call and at the service of society".

In general, the committee considers that the dependence of Canadian research and development on government funds is not yet the danger that some critics have argued it may become-one sign of this is that university projects for research and development are growing more quickly than those for government research. But the committee does consider that there is "a deplorable lack" of information on research in the humanities and the social sciences. One of the themes running through its argument is that there should in future be a much closer link between science and the social sciences and that the latter should get a larger share of the funds available.

On the organization of research in Canada, the committee has a lot to say about the relationship between the federal research councils. For one thing,

Table 1. TOTAL EXPENDITURE ON RESHARCH AND DEVELOPMENT IN CANADA, 1965

\begin{tabular}{|c|c|c|c|c|c|}
\hline Source of funds & $\begin{array}{c}\text { Goverm - } \\
\text { ment }\end{array}$ & $\begin{array}{l}\text { Indus- } \\
\text { try }\end{array}$ & $\begin{array}{l}\text { Higher } \\
\text { educa- } \\
\text { tion }\end{array}$ & $\begin{array}{c}\text { Private } \\
\text { non- } \\
\text { profit }\end{array}$ & Total \\
\hline Government & $241 \cdot 5$ & $49 \cdot 9$ & $57 \cdot 0$ & $2 \cdot 6$ & $35] \cdot 0$ \\
\hline Industry & $1 \cdot 4$ & $208 \cdot 5$ & $3 \cdot 0$ & $0 \cdot 1$ & $213 \cdot 0$ \\
\hline Higher education & - & 一 & $71 \cdot 0$ & 一 & $71 \cdot 0$ \\
\hline Private non-profit & 0.7 & 一 & $9 \cdot 0$ & $4 \cdot 4$ & $14 \cdot I$ \\
\hline Foreign & $0 \cdot 3$ & $25 \cdot 5$ & $6 \cdot 0$ & $0 \cdot 8$ & $32 \cdot 6$ \\
\hline Totals & $243 \cdot 9$ & $283 \cdot 9$ & $146 \cdot 0$ & $7 \cdot 9$ & $681 \cdot 7$ \\
\hline
\end{tabular}

following its policy of generosity towards the humanities and the social sciences, the report says that the responsibilities of the Canada Council for the support of some research in these fields should be handed over to a body called the Humanities and Social Sciences Council equipped to provide decisive management of research expenditure in universities. One of the difficulties in the present arrangements is that the Canada Council is responsible for the patronage of the arts as well as for the support of university research. The committee accepts much of the criticism which has been made of the Canada Council on this score and considers that the arts and the humanities will be better served if the Canada Council becomes simply a patron of the arts. The amounts of money concerned, although not large, are growing rapidly-the council spent $\$ 5.5$ million in $1966-67$ and more than twice as much in 1967-68.

The Medical Research Council, the newest of the devices for supporting Canadian research, is also growing quickly-expenditure on extramural research increased by 25 per cent to $\$ 20.5$ million in $1967-68$. The committee takes the view that the terms of reference of the Medical Research Council should be broadened so as to cover research in all branches of science related to health, particularly in public health and nursing. This recommendation fits in with that of the Royal Commission in 1964 which argued that the Medical Research Council should be renamed the Health Sciences Research Council. What the committee has taken as its model is the National Institutes of Health in the United States, but it is at pains to point out that the involvement of a broadened Medical Research Council in health sciences research should not inhibit executive agencies of the Canadian government, particularly the Department of National Health and Welfare, from supporting research of direct interest to themselves.

Underlying the committee's argument on the research councils is its objective that three councils should be responsible for the support of university research but should be left comparatively free of other responsibilities. The National Research Council, by now heavily engaged in various kinds of industrial research and, in particular, responsible for a number of laboratories of its own, is the most directly affected by the new proposals. The committee has the grace to recognize that the National Research Council has been pushed this way and that by government policy since it was first established in 1916, first having its industrial activities fostercd and then finding itself more at the beck and call of the universities. The committee points out that the National Research Council's expenditure on university research has been increasing at a rate of about $33 \frac{1}{3}$ per cent a year for the past few years and now amounts to more than 50 per cent of the total budget. The question is whether the National Research Council should keep its laboratories and the committee argues that it should not. For one 
thing, the scale of university support, running at $\$ 45$ million in 1967-68, is expected to grow quickly in the next few years and in particular is likely to grow to several times the size of the budget for the laboratories by the mid-seventies. In these circumstances, the committee argues, the laboratory work is likely to be neglected, particularly if the National Research Council takes on extra responsibilities for the support of students in research. The committee also wants to see the grant-giving functions of the council managed by full-time professionals and not, as at present, with substantial help from members of the council's staff mostly engaged in laboratory work. This leaves open the question of what would happen to the laboratories. The committee off its own bat suggests that a "new Crown corporation" might be a solution. Much of course will depend on how the Canadian government considers support for industrial development in manufacturing industry should be provided.

The committee has made somewhat heavy weather of the argument by which it concludes that the number of research councils with responsibility for university research should be neither increased nor decreased but, rather, deliberately left unchanged. The claim that there should be a single council is rejected on the grounds that such a body would be emasculated by the need to encompass everything-"the one strong voice would in all likelihood have become a pathetic squeak". The committee is against the establishment of further research councils, however, because, it says, proposals for these are usually stimulated by concern for national problems and because "we have reached the conclusion that it is inappropriate to clothe a problem area in the organizational garb of a research council". What the committee offers, instead, is a coordinating committee and it is only proper that the committee recognizes the inevitable limitations of such a body.

What should be the policy of the research councils? For one thing, the committee asks that there should be a flexible approach to the expenditure of money and it raises the question whether the natural sciences deserve 40 per cent of all that is spent in Canada on university research. Although it is inevitable that the research councils should devote much of their funds to fields already well developed, the committee asks that they should seek a balancing function, spending money on disciplines not well supported by other government agencies.

The committee argues for a greater variety of grants for university research than can be obtained at present. Much of the committee's argument is analogous to that of the National Science Board in the United States which, earlier this year, came out strongly in favour of a new pattern of grant giving. The Macdonald committee was less radical. On the making of individual project grants the committee argues that there should be a uniform system of review committees, with independent temporary members from the universities, to pass judgment on grant proposals. The committee also argues for research council grants to support the work of a group of investigators or of a research programme as a whole as well as for what it calls "major grants" such as those needed to build and operate large pieces of equipment such as the meson accelerator now being built. Much in the spirit in which the US National Science Board argued for departmental grants to build up centres of excellence in universities, so the Macdonald committee asks that there should be "negotiated development grants" of the kind already awarded by the National Research Council for the establishment of institutes such as a materials research centre (British Columbia, McMaster and Toronto) and a pestology centre (Simon Fraser). What the committee has in mind seems to be a pattern of grant giving in which sums of between $\$ 200,000$ and $\$ 1$ million are set aside for a period of a few years, but it also wants to see smaller sums of money paid for the development of new forms of activity.

Overheads and their place in research grants have exercised the Macdonald committee and it has laid down the principle that university salaries should be paid by universities and not by the research councils. In the committee's view, however, it would be proper that the research councils' grants should cover the direct cost of research programmes, including equip. ment and the cost of running it, travel and research assistants. What alarms the committee is that the rapid increase of the scale of sponsored research in universities may lead to a situation in which universities will not be able to "control their own destiny". But, even so, the committee considered that the dangers that universities will fight shy of research for fear that they cannot afford the overhead costs leads the committee to the view that research councils should also pay the indirect costs associated with research grants. On the basis of detailed studies carried out in recent years, it is concluded that 35 per cent of the direct cost of a research project should be added to cover overheads. One striking feature of the Macdonald report is its analysis of the legal framework for the relationships which still exist between a research council and its pensioners.

The report has rather less to say about the relationship between government laboratories and Canadian universities, although there is an exhortation about the desirability that government laboratories should be sited near universities and, where possible, managed by universities. The committce also wants to see government departments able to award grants for research in universities in fields which interest them, but it is firm on the distinction between missionoriented money for large projects ("major proposals"), which are legitimate, and other forms of support intended to support particular university departments or fields of research which, the committee says, should be left to the research councils. The committee does however take the view that neither the government nor the universities should undertake sponsored research from a government department the results of which cannot be published. "Any exception to this principle should be subject to the most formal review procedures in both the university and the agency conccrned." To be sure, the committee acknowledges that it may on many occasions be proper for sponsors to ask that raw data should be kept confidential-that is already common practice. It is also proper that sponsors should sometimes ask for the postponement of publication although the committee is inclined to take a stand on a one year rule. But the notion that research should be classified "at the sole discretion of the sponsoring agency" may do "irreparable violence to the most fundamental objectives of academic research".

The committee is downcast by the machinery and the scale of support for buildings at Canadian universities. It says that the point has almost been reached 
where Canadian universities will have to close their doors to would-be entrants to graduate schools for lack of buildings. It reports the way in which it was assailed by witnesses to the need for more buildings. The committee calculates that the real need of buildings for research in Canadian universities would predicate an expenditure of $\$ 117$ million a year for the next seven years, representing about 40 per cent of the total cost of university building. In practice, actual expenditure in 1963-64 amounted to $\$ 8$ million and in 1964-65 to $\$ 14.5$ million- "far short of any reasonable goal". A part of the trouble is that the need of buildings has been consistently under-estimated. What the committee wants to see is a separate programme for the construction of research facilities at Canadian universities with public money.

The committee takes a bullish view of the future development of graduate education in Canada. In the decade to 1966, graduate enrolments grew from 4 per cent of the university student population to roughly 9 per cent, and graduate students now number more than 30,000 . The committee has estimated that the growth of recent years will continue well into the seventies, and calculates that graduate students will number more than 60,000 by 1975 , when they will be close on 12 per cent of the whole student population at the universities. As things are, financial support for graduate students is provided in almost equal amounts by the provincial governments and by the central government, chiefly through the research councils, and the committee recommends that the governments should openly acknowledge that these costs are a necessary part of education and therefore allowable in calculating the balance of expenditure on education between the federal and the provincial governments.

\section{PRIZES \\ Harvard honours its Own}

Professor Wally Gilbert and Dr Mark Ptashne have been awarded Harvard University's George Ledlie Prize, a biennial prize, which since 1955 has gone to the faculty members making "the most valuable contribution to science or in any way for the benefit of mankind". The prize, more honour than cash (it is worth $\$ 1,600)$, is for their work on the isolation of repressor protein molecules which proved the hypothesis of genetic regulation proposed by the French Nobel Prizewinners F. Jacob and J. Monod. In bacteria and bacteriophages at least, repressor proteins bind to a gene or group of genes and as a result prevent the genetic information from being expressed. This repression is not, of course, irreversible. The repressor can also bind to small molecules of metabolites, and when this happens it is released from the gene, which can then be expressed (Nature, 21\%, 507; 1968).

\section{INFORMATION TRANSFER}

\section{Organizing the Literature}

THe number of research reports in all fields of science and technology is fast approaching two million a year, which appear in about 30,000 specialized journals. The amount of new research published each year has been doubling about every 10-15 years. With this flood of information new policies and methods for coordinating scientific communication are becoming crucially important. The US National Academy of Sciences-National Academy of Engineering's Committee on Scientific and Technical Communication (SATCOM) has just published a summary of its solution of the problem after a three-year study.

The ideal day when each research worker can have his own tailor-made information service is not in sight, but SATCOM believes that the immediate strategy must be the provision of "need group services"in other words, effective information services for professional groups of about 1,000 people, all sharing common information requirements. This means developing services to sift, evaluate, simplify and consolidate primary information and reprocess and repackage it, and SATCOM believes the existing abstracting services are not only too few but too superficial. The committee's grand strategy for adequate "need group services" hinges on establishing a Joint Commission on Scientific and Technical Communication, responsible to the councils of the two academies and with recognition by the Federal Government and private industry of the national importance of these services. They must foot the bills for information programmes developed along the lines of NASA's International Aerospace Abstracts and Scientific and Technical Aerospace Reports, both of which clearly impressed SATCOM during its enquiries. An integral part of this strategy, of course, is the acceptance by the research sponsors of the principle that they must finance publication and, if necessary, further processing of the results of the research.

The scientific and technical societies will play their part by identifying what critical reviews and compilations are really needed for their members, because SATCOM believes that simply supplying long reference lists is of little use. The report says that "what the research worker needs is something that will organize and evaluate what is known about a subject and present it in a language that he can understand and at a level of detail he wants". The societies must take the initiative by proposing to the sponsors of research costed arrangements for providing their members with adequate information services.

How do the classical services, ranging from abstracting to organizing meetings, fit into this picture? These, according to SATCOM, should be increasingly financed by Federal Government grants to the societies and libraries. In particular, the committee advocates direct government grants to strengthen research library services. Until a comprehensive survey of the economics of learned journals has been made, the committee also recommends that government grants to cover page charges should be continued. The importance of meetings and personal contacts has not been overlooked and SATCOM recommends not only that meetings should be fostered but also that institutions and companies should enoourage leave, sabbatical policies and international visits and exchanges.

Finally, the report calls for large scale experiments to test the usefulness and functioning of information services. It believes that the Federal Government should establish a single group to plan such a programme of critical experiments in scientific communication and then find, guide and support contractors to do the experiments. 